\title{
THERMAL COMFORT PROPERTIES OF CLOTHING FABRICS WOVEN WITH POLYESTER/COTTON BLEND YARNS
}

\author{
Hakan Özdemir \\ Dokuz Eylül University, Department of Textile Engineering, İzmir, Turkey, Tel: +90 232 3017736, \\ Fax: +90 232 3017750, e-mail: h.ozdemir@deu.edu.tr
}

\begin{abstract}
:
In this research, thermal and water vapor resistance, components of thermal comfort of 65/35 and 33/67\% polyester/ cotton (PES/CO) blend fabrics woven with 2/2 twill, matt twill, cellular and diced weaves, which are commonly used for clothing, were determined. The results indicate that both the fabric construction and the constituent fiber properties affect thermal comfort properties of clothing woven fabrics. Cellular weave, which is derivative of sateen weave and diced weave, which is compound weave, has the highest thermal resistance appropriating for cold climatic conditions. On the other hand, the 2/2 twill weave and matt twill weave, which is derivative of sateen weave, depicted the lowest water vapor thermal resistance, making it convenient for hot climatic conditions. Besides, fabrics woven with 65/35\% PES/CO blend yarns have higher thermal resistance, so they are suitable for cold climatic conditions. Fabrics woven with 33/67\% PES/CO blend yarns have lower water vapor resistance, so they are convenient for hot climatic conditions.
\end{abstract}

\section{Keywords:}

Thermal comfort, thermal resistance, water vapor resistance, woven fabrics, twill weave, derivative weave, compound weave

\section{Introduction}

The expectations from fabrics and clothes go up as a result of increase in life standard of people, as well as strength, esthetics design and fashion. Parallel to this, today's people expect different properties from clothes and fabrics such as sensing comfortable both at working and free times. In this context, clothing becomes important. And also, thermal comfort is one of the significant parameters of clothing comfort, which determines the degree of pleasures from physiological, psychological, and physical harmony between human body and environment. Thermal comfort is related to thermal and water vapor permeability properties of clothes. Clothes having better thermal comfort, protect thermal and humidity balance of human body by transferring human body's heat and moisture at various environmental conditions and activities [1, 2]. So, researchers have been investigating the thermal comfort properties of fabrics and fibers in recent years:

Wrobel, De Mey, and Van Langenhove [3] proposed the objective method for estimation of the thermal haptic perception of textiles, which is far more precise than traditional subjective methods, based on the assignment of certain verbal or numerical parameters to the perceived features of textiles. Ahmad et al. [4] investigated the relationship between fabric weave structure and its thermal resistances. They studied the two basic weave structures and four derivatives for each selected weave structure. While the plain weave structure showed the highest thermal resistance, the 2/2 matt weave depicted the lowest thermal resistance. Cybulska, Snycerski, and Ornat [5] designed protective garment from 2/1 twill and plain woven fabrics with polyester and silver yarns. They analyzed the workers' comfort by determining water vapor permeability. Laourine and Cherif [6] searched the water vapor transmission resistance in the plain weave gray fabrics with varying loom parameters. They found that the results did not offer any evidence regarding the effects of the machine parameters or fabric construction on the manufactured textile's water vapor transmission resistance. Behera [7] investigated the thermal insulation of $100 \%$ cotton, $100 \%$ linen, linen-cotton, linen-viscose various blended woven fabrics. He found that linen and linen-blended fabrics had higher thermal insulation values than cotton fabrics. Kakvan, Najar, and Psikuta [8] studied the thermal comfort properties of woven fabrics made of Kermel, cotton/nylon and cotton/nylon/Kermel-blended yarns. The results show that the thermal resistance increase with Kermel fiber blend ratio. Conversely, the water vapor resistance decreases with increase of Kermel fiber blend ratio up to $40 \%$, while $100 \%$ Kermel-woven fabric exhibits a higher water vapor resistance value. Mahbub et al. [9] investigated the thermal comfort properties of woven Kevlar/wool and woven Kevlar ballistic fabrics. While the thermal resistance of Kevlar/wool fabric was higher than that of Kevlar fabric, the water vapor resistance of Kevlar fabric was higher than that of Kevlar/wool fabric. Matusiak and Kowalczyk [10] investigated the relationships between the thermal insulation properties of single materials and multilayer textile packages composed of these materials, made of woven and knitted fabrics, as well as nonwovens.

Cotton, which has natural wicking and absorbing property, is important vegetable fiber because of $54 \%$ of world fiber production. It wrinkles and creases easily, and also its shrink ability is high. Polyester fibers are used as component of blend 
yarns, by taking advantages of their good properties such as high tensile and abrasion strength, dimension stability, noncreasable, as well as easy care in order to increase the usage value of blend yarns. The polyesters have interaction when they are blended with cotton during the decomposition process. The polyester/cotton fabrics, the blend has higher total heat release than the arithmetic sum of cotton and polyester as single fibers with a bit increase in the percent char yield, and its char yield increases as the cotton ratio in the blend decreases [11]. In this context, $65 / 35$ and $33 / 67 \%$ polyester/cotton (PES/CO) blend yarns show better performance than $100 \%$ cotton or polyester yarns.

Apart from three basic weaves; there are weaves derived from basic weaves to obtain physical and esthetic characteristics in the fabric somewhat different than those obtained with the basic weaves. This is achieved by rearranging the basic weave structures by the application of certain methods to give the desired result. In this way, ridges, indentations, cells, pores and so on can be obtained on the fabric surface by certain arrangement of floats in the weave unit of these simple single structures. Matt twills and cellular weaves are derivatives of sateen weaves. In addition to these, diced weaves can be obtained by combining different weaves as forming different sections of a small weave unit [12].

The studies in literature focused on fabrics woven with basic weaves such as plain, twill. However, matt twill, cellular and diced weaves have not been investigated. The aim of the study is to investigate the effects of weave and raw material on the thermal and water vapor resistance of some commonly used clothing $65 / 35$ and $33 / 67 \%$ PES/CO blend woven fabrics, whose weaves are 2/2 twill, matt twill, cellular and diced weaves.

\subsection{Thermal Comfort}

Clothes function as a protective buffer between human body and environment, so they play an important role in healthy life. It is closely related to physiologic materials and clothes that human being can accord to climatic conditions, they are able to move freely without feeling restraint and restriction and they can enjoy their activities.

Air layer, also called microclimate, which is between skin and cloth, determines the thermal comfort emotion. Microclimate is affected by environmental factors, levels of human activities, and clothes' properties. Environmental factors and human activities cannot be interfered up to intended measure, therefore; amendment of thermal comfort can be provided by changing clothes' properties. Thus, changing clothe's properties determines body comfort by affecting microclimate. Ideal clothing fabrics should have three important properties in terms of thermal comfort: i) High thermal resistance for protection from cold, ii) Low water vapor resistance for efficient heat transfer at mild climate conditions, iii) High rate of liquid transfer for preventing from discomfort of sweating.

Thermal resistance is a resistance that a surface resists to heat flow. Thermal resistance means heat difference at unit thickness of material, lasting unit time, and corresponding to unit area of material. Thermal resistance is related to thickness of material and calculated by [13];

$$
R_{d}=\frac{h}{k}
$$

where $R_{\mathrm{ct}}$ is thermal resistance $\left(\mathrm{m}^{2} \mathrm{KW}^{-1}\right), h$ is thickness of material $(\mathrm{mm}), k$ is coefficient of thermal conductivity $(\mathrm{W} / \mathrm{mK})$.

Water vapor permeability is ability of carrying water vapor. Water vapor permeability is critical for clothes designed for activities during which people consume huge amount of energy. Body, especially sweats to cool during doing these activities and so evaporation will be observed on body. Clothes should be able to remove moisture, which is composed due to the storage of moisture in clothes at cold conditions, from body in order to protect body comfort and to decrease thermal isolation of clothes.

Fabrics that are capable of breathing are able to provide extra heat loss by evaporating dampness in their layers. If the fabric layers are not be able to transfer water vapor, over humidity is stuck between skin and cloth and so the heat is accumulated in body. Heat and humidity deposition causes comfortless, wet skin, and adhesion of clothes. Water vapor resistance is a resistance of material to water vapor transition and calculated by [14];

$$
R_{e}=\frac{\left(P_{s}-P_{a}\right) \times A}{H}
$$

where $R_{\mathrm{et}}$ is total heat resistance of water vapor $\left(\mathrm{m}^{2} \mathrm{PaW}{ }^{-1}\right)$, which is provided by both fabric and air layer, $A$ is area of test plate $\left(\mathrm{m}^{2}\right), P_{\mathrm{s}}$ is water vapor pressure at plate surface $(\mathrm{Pa}), P_{\mathrm{a}}$ is water vapor pressure at air (Pa), $H$ is input power (W).

\section{Materials and methods}

\subsection{Materials}

$65 / 35$ and $33 / 67 \%$ PES/CO blend yarns have better performance than $100 \%$ cotton or polyester yarns. And also, $2 / 2$ twill, matt twill, cellular and diced woven fabrics are commonly used for men and woven clothing. So; in this research, 2/2 twill, matt twill, and diced woven fabric samples $(30 \times 30 \mathrm{~cm})$ were produced in the in-house Weaving Workshop by $\mathrm{CCl}$ automatic sample rapier loom (Evergreen 8900, Taiwan) with 67/33 and $35 / 65 \%$ PES/CO blend yarns. The counts of blend yarns were $\mathrm{Nm}$ 30. The weave interlacing coefficient, a fabric structural property, defined by Galcerán [15] was calculated by;

$$
\boldsymbol{K}=\frac{i}{w_{1} \times w_{2}}
$$

where $i$ is the number of interlacing points in weave repeat, $w_{1}$ is the number of ends in weave repeat, $w_{2}$ is the number of picks in weave repeat. While the weave patterns and fabrics used in experimental are shown in Figures 1 and 2, the specifications of fabrics are given in Table 1 . The desizing process was applied to all fabric samples. 


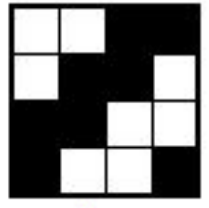

a

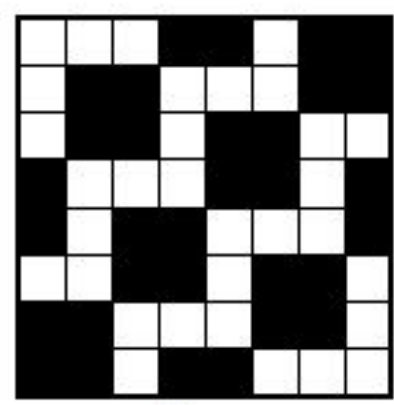

b

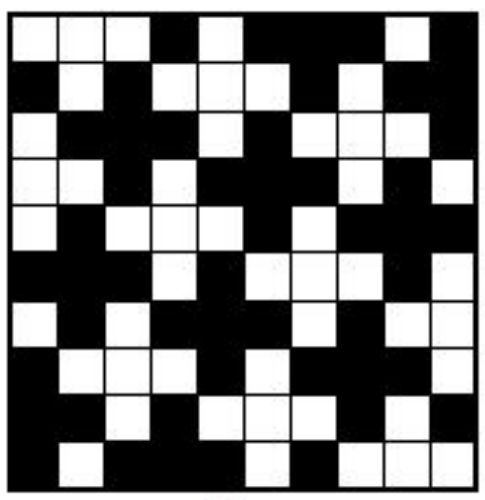

C

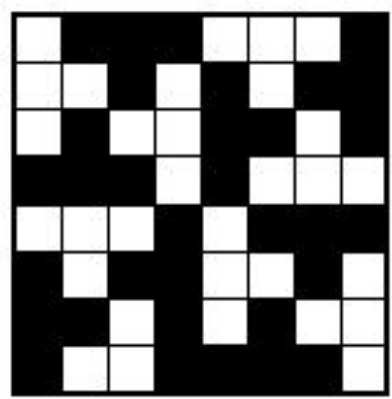

d

Figure 1. Fabric weave patterns used in the experimental: a) 2/2 twill, b) matt twill, c) cellular weave, d) diced weave

a

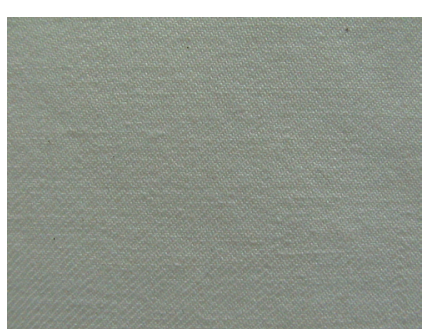

e

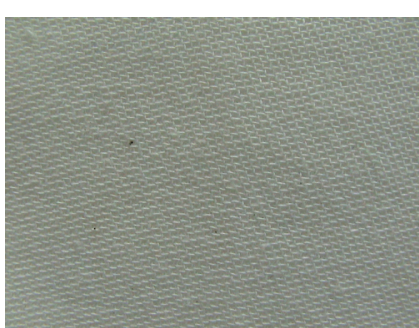

b

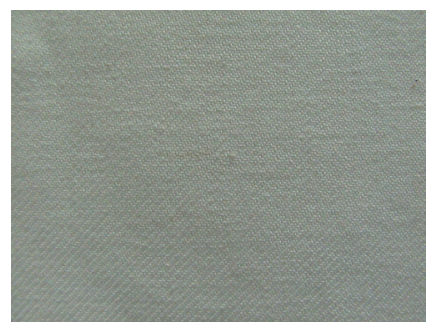

f

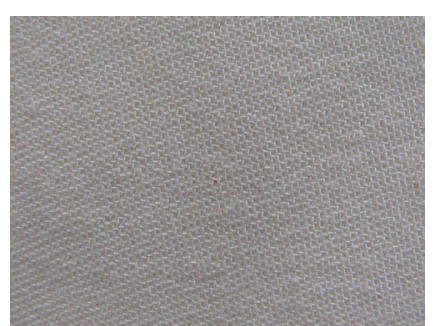

C

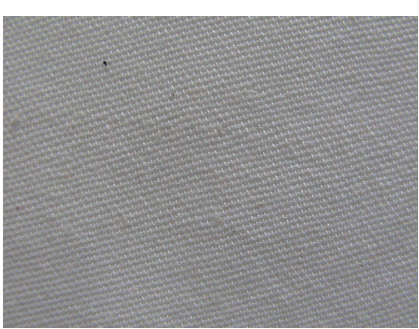

g

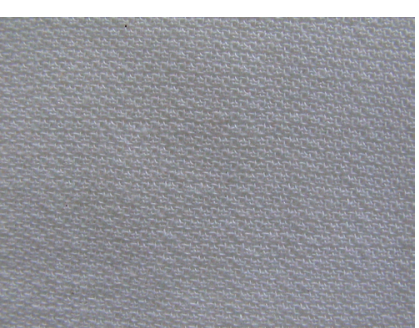

d

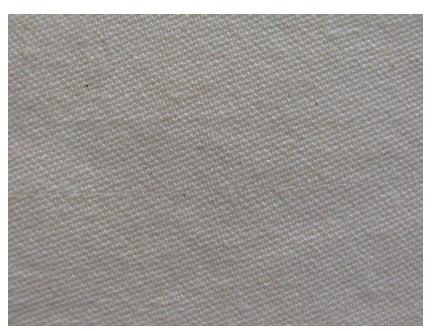

$\mathrm{h}$

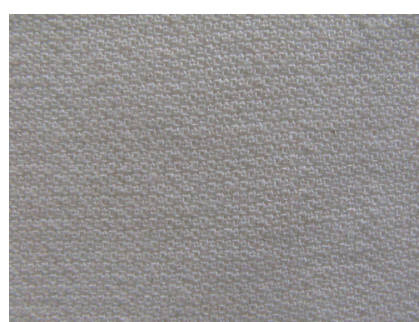

Figure 2. Fabrics used in the experimental: a) $2 / 2$ twill (65/35\% PES/CO), b) $2 / 2$ twill (33/67\% PES/CO), c) matt twill (65/35\% PES/CO), d) matt twill (33/67\% PES/CO), e) cellular weave (65/35\% PES/CO), f) cellular weave (33/67\% PES/CO), g) diced weave (65/35\% PES/CO), h) diced weave $(33 / 67 \%$ PES/CO)

Table 1. The specifications of fabrics

\begin{tabular}{|c|c|c|c|c|c|}
\hline Fabric code & Weave & Yarn & $\begin{array}{c}\text { Weave } \\
\text { interlacing } \\
\text { coefficient }\end{array}$ & $\begin{array}{l}\text { Warp density on } \\
\text { the loom }\end{array}$ & $\begin{array}{l}\text { Weft density on } \\
\text { the loom }\end{array}$ \\
\hline $\mathrm{A} 1$ & $2 / 2$ twill & $\begin{array}{c}\text { 65/35 polyester/ } \\
\text { cotton }\end{array}$ & 0,5 & 35 & 29 \\
\hline A2 & $2 / 2$ twill & $\begin{array}{c}\text { 33/67 polyester/ } \\
\text { cotton }\end{array}$ & 0,5 & 35 & 29 \\
\hline B1 & Matt twill & $\begin{array}{l}65 / 35 \text { polyester/ } \\
\text { cotton }\end{array}$ & 0,5 & 35 & 28 \\
\hline B2 & Matt twill & $\begin{array}{c}33 / 67 \text { polyester } \\
\text { cotton }\end{array}$ & 0,5 & 35 & 28 \\
\hline $\mathrm{C} 1$ & Cellular weave & $\begin{array}{l}65 / 35 \text { polyester/ } \\
\text { cotton }\end{array}$ & 0,6 & 35 & 33 \\
\hline $\mathrm{C} 2$ & Cellular weave & $\begin{array}{c}\text { 33/67 polyester/ } \\
\text { cotton }\end{array}$ & 0,6 & 35 & 33 \\
\hline $\mathrm{D} 1$ & Diced weave & $\begin{array}{c}65 / 35 \text { polyester/ } \\
\text { cotton }\end{array}$ & 0,5 & 35 & 30 \\
\hline D2 & Diced weave & $\begin{array}{c}\text { 33/67 polyester/ } \\
\text { cotton }\end{array}$ & 0,5 & 35 & 30 \\
\hline
\end{tabular}




\subsection{Methods}

\subsubsection{Yarn sizing and desizing}

The yarns did not have enough tensile strength, therefore; they were sized. Synthetic sizing liquors were prepared in-house finishing laboratory; Ensize TX11 5\% was used for size recipe. Moreover, Wachs $2 \%$ of sizing agent was also added to all size recipes. Size liquors were heated up to $80^{\circ} \mathrm{C}$ and scoured at $80^{\circ} \mathrm{C}$ for 20 minute. The temperature of sizing chamber was set at $80^{\circ} \mathrm{C}$, whereas temperature of heating chamber was set at $86^{\circ} \mathrm{C}$ during the sizing process. All the conditions mentioned did not change during the process, so it can be claimed that the conditions for all the yarns tested were the same.

All fabric samples after woven, were applied desizing process, in order protect test result from sizing agents, in-house of fastness laboratory at $60^{\circ} \mathrm{C}$ during 20 minute.

\subsubsection{Testing of thermal comfort}

The Sweating Guarded Hotplate (often referred to as the "skin model") is intended to simulate the heat and mass transfer processes that occur next to the surface of the skin. The Sweating Guarded Hotplate is shown in Figure 3.

The tests were performed in the environment with a relative humidity range of $65 \pm 3 \%$ non-condensing and the ambient temperature was $20 \pm 1^{\circ} \mathrm{C}$ according to ISO 11092 [16]. The test specimens were cut diagonally to the size of $300 \times 300 \mathrm{~mm}$ and conditioned at standard atmospheric conditions during 12 hours. The Measuring Table Control was adjusted (Up or Down Adjustment) to level the measuring unit with chamber air outlet. And also, position of air sensor was adjusted at a point $15 \mathrm{~mm}$ above the measuring unit.
The parameter of test chamber was set up by a computer connected to the test chamber with a USB cable. Thermal Test $\left(R_{c t}\right)$ or Water Vapor Test $\left(R_{e t}\right)$ was selected in the Test Configure page. Test time was entered as 15 minutes. To measure the Bare Plate thermal resistance, the measuring unit was left uncovered and the test was started by clicking "Next Step." And then the Bare Plate value was determined, and entered in $R_{c t} 0$ or in $\mathrm{R}_{\mathrm{et}} 0$. The test results $\left(\mathrm{R}_{\mathrm{ct}}\right.$ or $\left.\mathrm{R}_{\mathrm{et}}\right)$ automatically subtracted this $\mathrm{R}_{\mathrm{ct}} \mathrm{O}$ or $\mathrm{R}_{\mathrm{et}} \mathrm{O}$ value.

The software configured the setting of test chamber and ran it. Machine was waited to stabilize all parameters at the set point approximately 40 to 90 minutes. The System Conditions screen showed the actual values of machine. The data and result $\left(R_{c t}\right)$ or $\left(R_{\text {et }}\right)$ were captured every 15 minutes. The software determined whether the parameters and $R_{c t}$ or $R_{\text {et }}$ value fell within the acceptance tolerance and indicated this in green or red color; green for pass and red for fail. For Bare plate resistance $\left(R_{c t} 0\right)$ or $\left(R_{e t} 0\right)$, all parameters were waited to fall within tolerance (in green color), then, $\mathrm{R}_{\mathrm{ct}} \mathrm{O}$ or $\mathrm{R}_{\mathrm{et}} \mathrm{O}$ was calculated by mean value of three consecutive similar results.

The specimen should be positioned on the measuring unit and left for approximately 15-30 minutes in order to reach steady state with the machine. The specimen was laid across the measuring unit and kept flat, and any bubbles were removed. The test could be deemed to be complete when three consecutive similar results fell within tolerance (in green color). Final result should be the mean value of these three similar results.

The specimen was removed and waited for 15 minutes to let the machine stabilize before testing next specimen. The results could be saved to a Microsoft Excel file anytime during the test. The user can edit any data on the Excel file. Entering the Bare

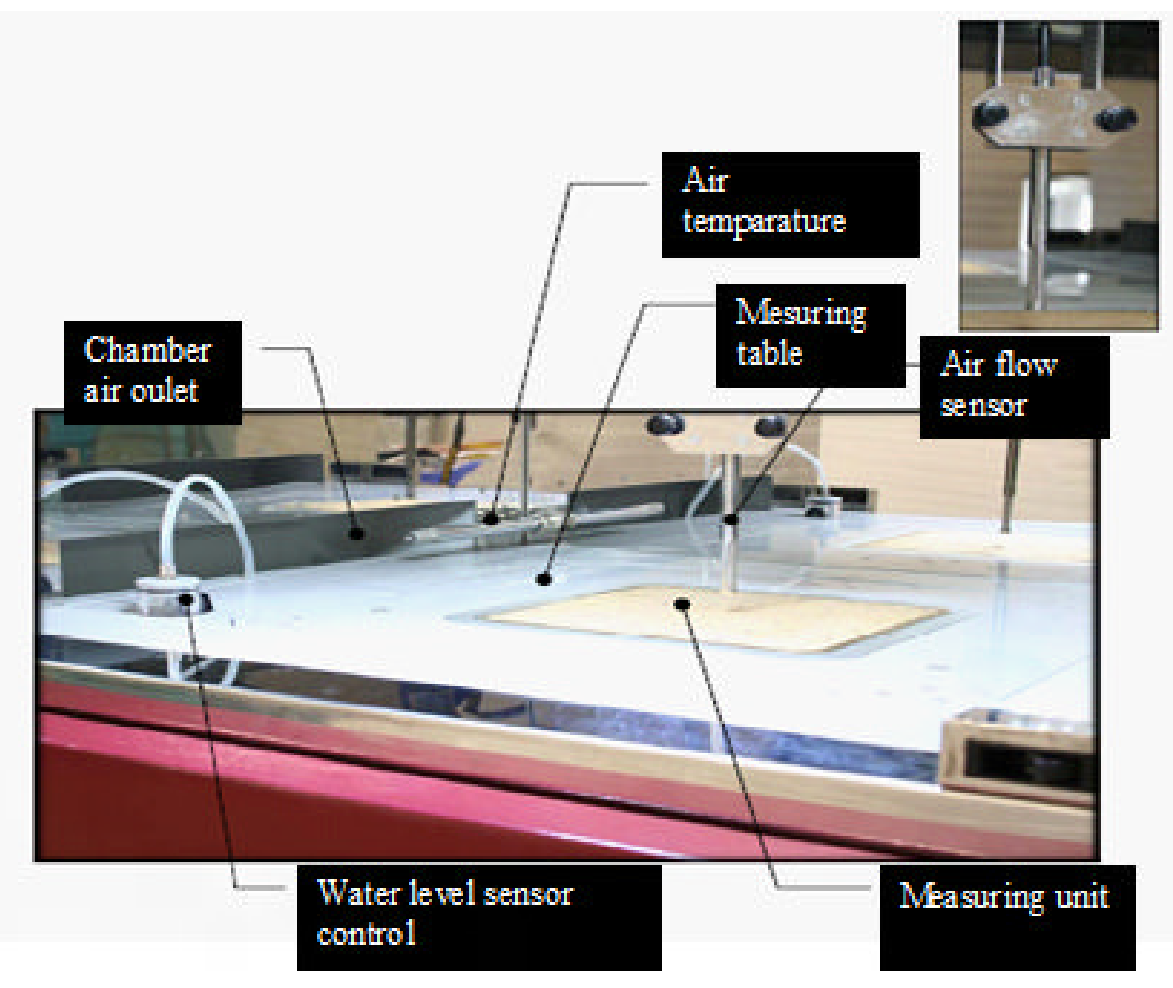

Figure 3. The Sweating Guarded Hotplate 
Plate value in the field will result in the $R_{c t} 0$ or $R_{e t} 0$ value being subtracted from all $R_{c t}$ or $R_{e t}$ results.

\subsubsection{Statistical evaluation}

The effect of raw material on thermal and water vapor resistance of fabrics was evaluated by $t$ tests for fabrics, woven with $65 / 35$ and $33 / 67 \%$ PES/CO yarn, with the same weave. $t$ tests were done by MATLAB 6.5 with significance level $(\alpha)$ of 0.05 also. Hypothesis of h0 defined that averages were equal. If $h$, the calculated value, is equal to 1 and $p$, the significance value $(p)$ is lower than 0,05 , h0 would be ignored, namely; the difference between the test results is statistically important. Since one sample for each fabric type was tested, the ANOVA could not be performed to determine the effect of weave.

\section{Results and discussion}

While the results of thermal tests are given in Table 2, the individual value plot for thermal resistance and fabric samples is shown in Figure 4. D1 has the highest thermal resistance among the fabrics woven with $65 / 35 \%$ PES/CO blend yarns. This is because of the fact that in diced weave, warp floats and weft floats come side by and side in sections, which cause ridges, indentations, and cells in fabric surface. Besides, C2 has the highest thermal resistance among the fabrics woven with $33 / 67 \%$ PES/CO blend yarns. This is due to the fact that cellular weaves are produced by placing weft and warp yarn floats end-to-end, in order to form cellular structures, which are indenting and protruding. On the other hand, $A 1$ and B2 has the lowest thermal resistance, this probably results from the facts that $2 / 2$ twill and matt twill weaves have smoother surface and

Table 2. Results of thermal test

\begin{tabular}{|c|c|c|c|c|c|}
\hline & $\mathrm{R}_{\mathrm{ct}} 0$ & $\mathrm{R}_{\mathrm{ct}} 1$ & $\mathrm{R}_{\mathrm{ct}} 2$ & $\mathrm{R}_{\mathrm{ct}} 3$ & $\mathrm{R}_{\mathrm{ct}}$ \\
\hline \multirow{3}{*}{$\mathrm{A} 1$} & 0.0976 & 0.1202 & 0.1167 & 0.1172 & \\
\hline & 0.0983 & 0.1181 & 0.1186 & 0.1176 & \\
\hline & 0.0994 & 0.119 & 0.115 & 0.1169 & \\
\hline Average & 0.0984 & 0.1191 & 0.1167 & 0.1172 & 0.0255 \\
\hline \multirow{3}{*}{$\mathrm{A} 2$} & 0.0976 & 0.113 & 0.1178 & 0.1203 & \\
\hline & 0.0973 & 0.1145 & 0.1158 & 0.1199 & \\
\hline & 0.0983 & 0.1157 & 0.1158 & 0.119 & \\
\hline Average & 0.0977 & 0.1144 & 0.1165 & 0.01197 & 0.0253 \\
\hline \multirow{3}{*}{ B1 } & 0.0969 & 0.1229 & 0.1211 & 0.1223 & \\
\hline & 0.0993 & 0.1229 & 0.1242 & 0.1229 & \\
\hline & 0.0966 & 0.1197 & 0.1211 & 0.1232 & \\
\hline Average & 0.0976 & 0.1218 & 0.1221 & 0.1228 & 0.0269 \\
\hline \multirow{3}{*}{ B2 } & 0.1155 & 0.1179 & 0.1181 & 0.1176 & \\
\hline & 0.1146 & 0.1191 & 0.1175 & 0.1182 & \\
\hline & 0.1161 & 0.1198 & 0.1183 & 0.1174 & \\
\hline Average & 0.1154 & 0.1189 & 0.1179 & 0.1177 & 0.0239 \\
\hline \multirow{3}{*}{ C1 } & 0.1169 & 0.1268 & 0.1303 & 0.1269 & \\
\hline & 0.1194 & 0.1288 & 0.1286 & 0.1298 & \\
\hline & 0.1189 & 0.1269 & 0.1304 & 0.1302 & \\
\hline Average & 0.1184 & 0.1275 & 0.1297 & 0.1289 & 0.0267 \\
\hline \multirow{3}{*}{$\mathrm{C} 2$} & 0.1159 & 0.1249 & 0.1244 & 0.1277 & \\
\hline & 0.1161 & 0.1261 & 0.1246 & 0.1258 & \\
\hline & 0.1171 & 0.1271 & 0.1277 & 0.1279 & \\
\hline Average & 0.1164 & 0.126 & 0.1256 & 0.1271 & 0.0262 \\
\hline \multirow{3}{*}{ D1 } & 0.0969 & 0.1232 & 0.1252 & 0.1278 & \\
\hline & 0.0967 & 0.1257 & 0.1254 & 0.1276 & \\
\hline & 0.0993 & 0.1253 & 0.1257 & 0.1277 & \\
\hline Average & 0.0976 & 0.1247 & 0.1254 & 0.1277 & 0.028 \\
\hline \multirow{3}{*}{$\mathrm{D} 2$} & 0.0969 & 0.1192 & 0.1231 & 0.1228 & \\
\hline & 0.0993 & 0.1202 & 0.1215 & 0.1226 & \\
\hline & 0.0966 & 0.1207 & 0.1238 & 0.1224 & \\
\hline Average & 0.0976 & 0.12 & 0.1228 & 0.1226 & 0.0242 \\
\hline
\end{tabular}


these weaves have lower weft densities among the weaves in which the weave interlacing points are equal to each other.

Thermal resistance of $A 1, B 1, C 1$, and D1, woven with $65 / 35 \%$ $\mathrm{PES} / \mathrm{CO}$ blend yarns, are higher than those of $\mathrm{A} 2, \mathrm{~B} 2, \mathrm{C} 2$, and D2, woven with $33 / 67 \%$ PES/CO blend yarns. This difference results from the fact that thermal resistance of polyester fibers is higher than that of cotton fibers. And also, $t$ test results show that the raw material has a significant effect on the thermal resistance of fabrics $(h=1, p=0.0435)$.

The results of water vapor tests are given in Table 3, whereas the individual value plot for water vapor resistance and fabric sample is shown in Figure 5. C1 has the highest water vapor resistance among the fabrics woven with $65 / 35 \%$ PES/CO blend yarns. And also, C2 has the highest water vapor resistance among the fabrics woven with $33 / 67 \%$ PES/CO blend yarns. This results from the facts that cellular weave has a surface with ridges, indentations and cells and also the highest weave interlacing coefficients. On the other side, $A 1$ and $A 2$ have the lowest water vapor resistance, this is probably because of the facts that the $2 / 2$ twill weave has smoother surface and this weave has lower weft density among the weaves in which the weave interlacing coefficient is equal to each other.

Water vapor resistance of $\mathrm{A} 2, \mathrm{~B} 2, \mathrm{C} 2$, and $\mathrm{D} 2$, woven with $33 / 67 \%$ PES/CO yarns, are lower than those of A1, B1, C1, and D1, woven with $65 / 35 \%$ PES/CO yarns. This difference results from wicking and absorbing properties of cotton fibers. But, $t$

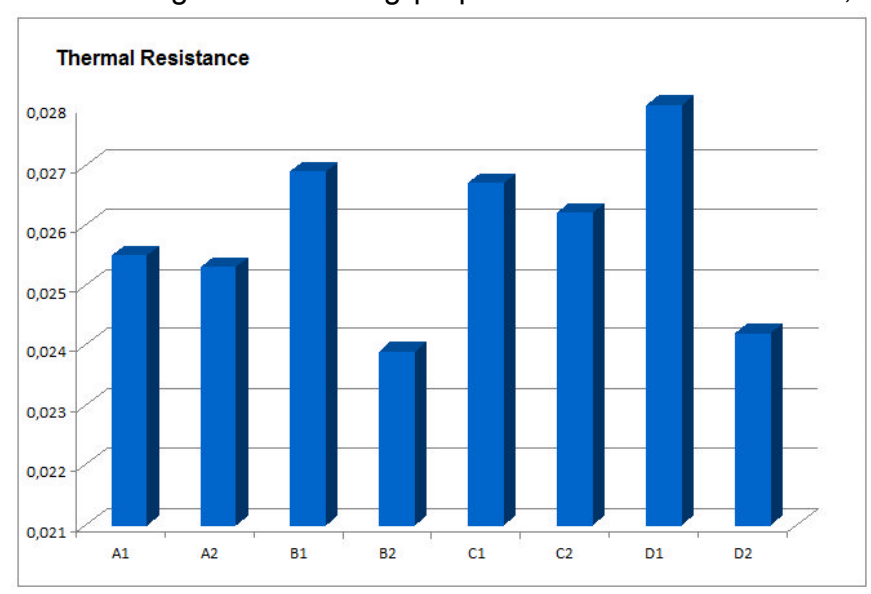

Figure 4. Individual value of thermal resistance vs. weave structure

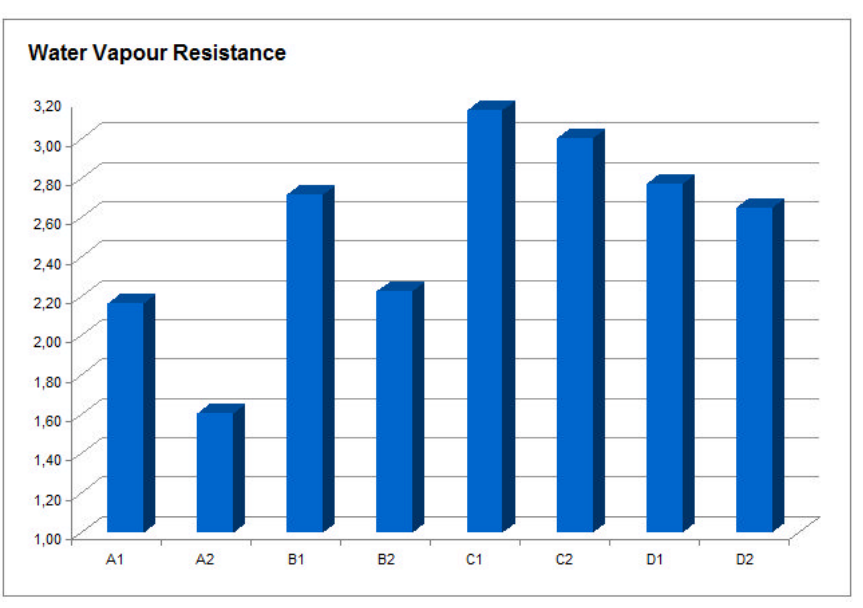

Figure 5. Individual value of water vapor resistance vs. weave structure test results show that the raw material has not a significant effect on the thermal resistance of fabrics $(h=0, p=0.3981)$.

Table 3. Results of water vapour test

\begin{tabular}{|c|c|c|c|c|c|}
\hline & $R_{e t} 0$ & $R_{e t} 1$ & $R_{\mathrm{et}} 2$ & $\mathrm{R}_{\mathrm{et}} 3$ & $\mathbf{R}_{\text {et }}$ \\
\hline \multirow{3}{*}{ A1 } & 7,3615 & 8,9388 & 9,6772 & 9,6602 & \\
\hline & 7,3889 & 8,9463 & 9,6554 & 9,6884 & \\
\hline & 7,3634 & 9,9276 & 9,6694 & 9,6734 & \\
\hline Average & 7,3713 & 9,2709 & 9,6673 & 9,674 & 2,1661 \\
\hline \multirow{3}{*}{ A2 } & 7,2844 & 8,8334 & 8,8573 & 8,9742 & \\
\hline & 7,2468 & 8,8972 & 8,8862 & 8,9972 & \\
\hline & 7,3562 & 8,7351 & 8,6973 & 9,2449 & \\
\hline Average & 7,2958 & 8,8219 & 8,8136 & 9,0721 & 1,6067 \\
\hline \multirow{3}{*}{ B1 } & 7,3779 & 10,4388 & 9,5225 & 10,3741 & \\
\hline & 7,3499 & 10,1717 & 9,515 & 10,443 & \\
\hline & 7,4092 & 10,3688 & 9,728 & 10,2778 & \\
\hline Average & 7,379 & 10,3264 & 9,5885 & 10,365 & 2,7143 \\
\hline \multirow{3}{*}{ B2 } & 7,3643 & 9,5152 & 9,7536 & 9,7362 & \\
\hline & 7,3587 & 9,378 & 9,5869 & 9,7265 & \\
\hline & 7,4462 & 9,4472 & 9,6782 & 9,7288 & \\
\hline Average & 7,3897 & 9,4468 & 9,6729 & 9,7305 & 2,227 \\
\hline \multirow{3}{*}{$\mathrm{C} 1$} & 7,4661 & 10,7071 & 10,4636 & 10,559 & \\
\hline & 7,35 & 10,6988 & 10,4572 & 10,5689 & \\
\hline & 7,4512 & 10,7563 & 10,4723 & 10,448 & \\
\hline Average & 7,4224 & 10,7207 & 10,4644 & 10,5253 & 3,1477 \\
\hline \multirow{3}{*}{$\mathrm{C} 2$} & 7,3868 & 10,2721 & 10,4522 & 10,2518 & \\
\hline & 7,3449 & 10,5862 & 10,4788 & 10,2541 & \\
\hline & 7,4092 & 10,4366 & 10,4452 & 10,2775 & \\
\hline Average & 7,3803 & 10,4316 & 10,4587 & 10,2611 & 3,0035 \\
\hline \multirow{3}{*}{$\mathrm{D} 1$} & 7,6975 & 10,2069 & 10,1844 & 10,5371 & \\
\hline & 7,3889 & 10,2173 & 10,1962 & 10,5488 & \\
\hline & 7,5275 & 10,1998 & 10,1795 & 10,5278 & \\
\hline Average & 7,538 & 10,208 & 10,1867 & 10,5379 & 2,7729 \\
\hline \multirow{3}{*}{ D2 } & 7,5054 & 10,2046 & 10,252 & 10,2177 & \\
\hline & 7,6259 & 10,1947 & 10,2564 & 9,778 & \\
\hline & 7,5049 & 10,2135 & 10,2789 & 10,3356 & \\
\hline Average & 7,5454 & 10,2043 & 10,2624 & 10,1104 & 2,647 \\
\hline
\end{tabular}

\section{Conclusions}

In this study, statistical and experimental studies were conducted to determine the effects of weave and raw material 
on the thermal comfort properties of some clothing fabrics woven with different percentage ratio of PES/CO blend yarns. As the thermal comfort property is related to thermal and water vapor resistance, these parameters are discussed individually:

The research results proved that the effect of raw material on the thermal resistance of the fabrics is statistically important. Although cotton fibers have high affinity to moisture, the effect of raw material on the water vapor resistance of the fabrics is not statistically important. While the fabric samples, woven with $65 / 35 \%$ PES/CO blend yarns, are convenient for winter clothing, the fabric samples, woven with $33 / 67 \%$ PES/CO blend yarns, are suitable for summer clothing because cotton fibers function as microclimate by means of their high rate of humidity transfer, especially at high temperature.

With the intending and protruding surface and highest weave interlacing coefficients, cellular woven fabric sample has the highest thermal and water vapor resistances, except for that woven with $65 / 35 \%$ PES/CO blend yarns. And also, thanks to similar surface characteristic, diced fabric sample woven with $65 / 35 \%$ PES/CO blend yarns has the highest thermal resistance. Therefore, these fabrics are suitable for winter clothing.

2/2 twill and matt twill fabric samples, woven with lower weft densities, the surfaces of which are smoother than cellular and diced weaves, have lower water vapor resistance. Thus, these fabrics are convenient for summer clothing.

\section{References}

[1] Das, B., Das, A., Kothari, V.K., Fanguiero, F., de Araújo, M. (2007). Moisture transmission through textiles Part I: Processes involved in moisture transmission and the factors at play. AUTEX Research Journal, 7(2), 100-110.

[2] Das, B., Das, A., Kothari, V.K., Fanguiero, F., de Araújo, M. (2007). Moisture transmission through textiles Part II: Evaluation Methods and Mathematical Modelling. AUTEX Research Journal, 7(3), 194-216.

[3] Ciesielska-Wrobel, I., De Mey, G., Van Langenhove, L. (2016). Dry heat transfer from the skin surface into textiles: subjective and objective measurement of thermal haptic perception of textiles - preliminary studies, The Journal of The Textile Institute, 107(4), 445-455.
[4] Ahmad, S., Ahmad, F., Afzal, A., Rasheed, A., Mohsin, M., Ahmad, N. (2015). Effect of weave structure on thermo-physiological properties of cotton fabrics. AUTEX Research Journal, 15(1), 30-34.

[5] Cybulska, M., Snycerski, M., Ornat, M. (2002). Qualitative Evaluation of protective fabrics. AUTEX Research Journal, 2(2), 69-77.

[6] Laourine, E., Cherif, C. (2011). Characterisation of barrier properties of woven fabrics for surgical protective textiles. AUTEX Research Journal, 11(2), 31-36.

[7] Behera, B.K. (2007). Comfort and handle behaviour of linen-blended fabrics. AUTEX Research Journal, 7(1), 33-47.

[8] Kakvan, A., Najar, S.S., Psikuta, A. (2015). Study on effect of blend ratio on thermal comfort properties of cotton/nylon-blended fabrics with high-performance Kermel fibre. The Journal of The Textile Institute, 106(6), 674-682.

[9] Mahbub, R.F., Wang, L., Arnold, L., Kaneslingam, S., Padhye, R. (2014). Thermal comfort properties of Kevlar and Kevlar/wool fabrics. Textile Research Journal, 84(19), 2094-2102.

[10] Matusiak, M., Kowalczyk, S. (2014). Thermal-insulation properties of multilayer textile packages. AUTEX Research Journal, 14(4), 299-307.

[11] Chen, Q., Zhao, T. (2015). The thermal decomposition and heat release properties of the nylon/cotton, polyester/ cotton and Nomex/cotton blend fabrics. Textile Research Journal, DOI: 10.1177/0040517515617423, 1-10.

[12] Başer, G. (2004). Technique and art of weaving (Vol. 1). Izmir: Punto (in Turkish).

[13] Das, A., Alagirusamy, R., Kumar, P. (2011). Study of heat transfer through multilayer clothing assemblies: a theoretical prediction. AUTEX Research Journal, 11(2), 54-60.

[14] Uğur, Ş.S., Sivri, Ç. (2008). The comparison of water vapour measurement techniques for textiles. Electronic Journal of Textile Technologies, (3), 13-20 (in Turkish).

[15] Galceran, V. (1962). Weaving technology. Terrassa: Technical University of Catalonia (in Spanish).

[16]ISO 11092 (2014). Textiles - Physiological effects Measurement of thermal and water-vapour resistance under steady-state conditions (sweating guarded-hotplate test) 